\title{
Masalah Transportasi Kota dan Pendekatan Psikologi Sosial
}

\author{
Juneman \\ Ikatan Psikologi Sosial, Himpunan Psikologi Indonesia
}

The writer of this article tried to clear up urban transport problems using social psychology approach. The first major problem is about traffic jam, which is analyzed by the concept of Tragedy of the Commons (Hardin, 1968). The second major difficulty is the traffic accidents which are analyzed by the risk theories of Wilde (1982, 1998), Summala (1974, 1997), and Fuller (2000). The writer also delivers the influence of illusion of control, optimism bias, and locus of control on risk taking decision. Moreover, the writer offers three solutions for each of the problems and the solutions are intended for individual level, cultural level and structural level. It is expected that this writing will give a theoretical contributions in the subject of transportation psychology in Indonesia. Transportation psychology is a relatively new field of applied psychology in Indonesia, and there is not much yet attention and development given to this particular subject. It is also expected that this writing gives ideas for transportation policies made by the governmental officers, especially in Indonesia's big cities.

Keywords: traffic-jam, traffic accidents, transportation psychology, tragedy of the commons, risks theory, urban transport policies

Dua masalah utama yang sering terjadi pada dunia transportasi di kota besar, seperti Jakarta, adalah (1) kemacetan, dan (2) kecelakaan lalu lintas. Ungkapan Cahyo Wardana, warga Pamulang, Tangerang Selatan berikut ini (“Jakarta Mengarah”, 2009) mewakili keluhan hampir seluruh warga kota besar mengenai permasalahan yang pertama:

Saya ini kerja di kota, tetapi pola berangkatnya seperti petani di desa. Sebelum matahari terlalu tinggi, saya harus segera meninggalkan rumah. Saya harus meninggalkan rumah sebelum pukul 06.00 agar dapat sampai di kantor sebelum pukul 08.00. Jika berangkat sesudah pukul 06.20, saya butuh waktu tiga jam untuk menempuh perjalanan 27 kilometer ke kantor.

Menurut Ketua Umum Masyarakat Transportasi Indonesia, Bambang Susanto (2006), berkebalikan dengan keyakinan umum, untuk pusat kota, yang diperlukan adalah mengelola kebutuhan (transport demand management) dan bukannya menambah jalan baru. Jalan baru di tengah kota dianggap akan membangkitkan lalu lintas baru (latent demand), yang pada akhirnya justru akan menambah kemacetan.

Permasalahan lainnya adalah kecelakaan lalu lintas. Angka kecelakaan lalu lintas pada 2009 mencapai 19.000 kasus. Menurut Menteri Perhubungan Jusman Sfafii Djamil di Jakarta (“Angka Kecelakaan”, 2009), jumlah ini naik dibanding tahun sebelumnya yang mencapai 18.000 kasus. Sebanyak 70 persen penyumbang kecelakaan adalah kendaraan roda dua. Berdasarkan data yang 
diperoleh dari Polda Metro Jaya, sedikitnya empat orang tewas setiap harinya akibat kecelakaan lalu lintas di Jakarta, dan setiap harinya terjadi sekitar 20 kasus kecelakaan di seluruh wilayah Jakarta ("Di Jakarta", 2009). Umumnya korban kecelakaan merupakan pengendara sepeda motor. Sementara itu, angka kecelakaan lalu lintas yang melibatkan bus Trans Jakarta (busway) mengalami peningkatan tiap tahun, dalam hal mana angka kecelakaan hingga Oktober 2009 menembus 268 kasus ("Sepanjang 2009”, 2009). Faktor utamanya adalah semua koridor busway tidak steril karena dimasuki kendaraan lain.

Mencermati fenomena transportasi kota di atas, psikologi sosial sebagai "Ilmu pengetahuan yang mempelajari tingkah laku individu sebagai fungsi dari rangsang-rangsang sosial" (Shaw \& Costanzo, 1970) sangat berkepentingan untuk memainkan perannya dalam memahami (dalam dimensi ontologis) sekaligus menawarkan pemecahan masalah (dalam dimensi aksiologis) atas “permasalahan kronis" yang menjangkiti kota-kota besar di Indonesia tersebut.

\section{Kemacetan Lalu Lintas}

Kemacetan lalu lintas merupakan salah satu masalah utama dalam dunia transportasi di kota besar. Waktu tempuh untuk jarak yang sama dari waktu ke waktu mengalami penambahan. Masalah klasiknya adalah bahwa pertambahan jalan tidak sebanding dengan pertambahan jumlah kendaraan bermotor. Sebagai contoh, angka kepemilikan sepeda motor setiap tahunnya mengalami kenaikan yang signifikan. Jika pada 2005 jumlah sepeda motor mencapai 4,4 juta unit, kini di tahun 2009 jumlah kendaraan roda dua ini naik menjadi 7,3 juta unit ("Di Jakarta", 2009).

Pada kebanyakan wilayah, jalan memang merupakan milik bersama warga kota (public goods) yang bebas digunakan oleh siapa saja. Namun, kerap kali jalan digunakan secara tidak tertib sehingga mengurangi nilainya bagi setiap orang. Setiap orang ingin menggunakan jalan secara berlebihan. Sementara itu, tidak ada insentif finansial sekecil apapun sekiranya orang tidak melakukan penggunaan jalan secara berlebihan. Setiap individu berupaya untuk tiba di tempat tujuannya dengan kendaraannya secepat mungkin dengan melalui rute-rute tercepat. Pada awalnya, setiap tambahan pengendara di jalan tidak memperlambat lalu lintas. Hal ini karena terdapat kemungkinan momen-momen "kelancaran lalu lintas kecil-kecil" yang cukup untuk menampung pengendara tambahan. Kendati demikian, pada sejumlah fase kritis, setiap tambahan pengendara mengakibatkan pengurangan kecepatan rata-rata dari semua kendaraan. Pada akhirnya, terdapat terlalu banyak pengendara sehingga lalu lintas padat-merayap.

Masalah ini dapat ditinjau dari kacamata psikologi sosial sebagai contoh modern dari gejala The Tragedy of the Commons (Tragedi Bersama) yang dikemukakan oleh Garret Hardin (1968). Guna memahami Tragedi Bersama, mari kita simak ilustrasi berikut ini.

Bayangkan diri Anda berada dalam sebuah lingkungan pedesaan dengan kampung-kampung yang dikelilingi oleh padang rumput di mana para gembala dapat bebas menggembalakan dombanya. Padang rumput, yang merupakan tempat bersama (the commons) itu, tersedia bagi semua gembala tanpa pembatasan. Bayangkan bahwa padang rumput tersebut menampung dombadomba dalam jumlah maksimum tertentu. Terdapat jumlah rerumputan yang cukup untuk seluruh 
domba tersebut untuk terberi makan dengan baik. Menambahkan satu domba lagi saja akan mengurangi jumlah makanan bagi domba-domba yang lain. Namun demikian, tiap-tiap gembala berpikir bahwa meningkatkan jumlah gembalaannya akan merupakan hal yang menguntungkan. Lebih banyak domba yang digembalakan berarti dapat dihasilkan lebih banyak wol dan lebih banyak penghasilan bagi gembala. Terdapat pula kerugian bila hal ini dilakukan, yakni jumlah makanan akan berkurang sedikit bagi domba-domba yang lain, termasuk domba gembalaannya sendiri. Namun, ketidakuntungan ini kelihatannya kecil karena tersebar merata diantara dombadomba. Jadi, dari sudut pandang masing-masing gembala, perolehan yang didapatnya besar, sementara kerugian yang diakibatkan oleh tindakannya adalah kecil. Tragedi terjadi ketika semua gembala melakukan hal yang sama, karena "kerugian yang kecil-kecil" tadi kemudian lalu meningkat menjadi "bencana” bagi setiap orang.

Berdasarkan kacamata psikologi sosial di atas, maka setiap pengendara yang (1) berupaya untuk mencari jalan pintas atau jalan tercepat, (2) tidak mau berkorban untuk melalui jalan dengan rute normal atau yang agak lebih panjang, (3) mencoba mengambil keuntungan dengan melanggar lampu lalu lintas saat tidak ada polisi yang mengawasi, (4) "tidak mau rugi" dengan menggunakan setiap ruas jalan apapun yang bisa digunakan (termasuk trotoar pejalan kaki) untuk dilalui atau pun untuk tempat parkir, (5) setuju untuk memanfaatkan jasa pungli (pungutan liar) untuk mempercepat waktu tempuh, demikian juga (6) penggunaan kendaraan individual yang bersifat masif (tidak mau beralih menggunakan transportasi masal umum) sementara tidak selalu ada pertambahan jalan, (7) supir angkutan umum yang ngetem beberapa saat untuk mencari penumpang, maupun (8) calon penumpang yang memberhentikan kendaraan umum bukan di halte yang semestinya, sesungguhnya telah bersama-sama "berkonspirasi" untuk menjamin waktu tempuh berkendara yang lebih panjang bagi setiap orang.

Puncak tragedi bersama yang dapat kita bayangkan adalah bahwa semua kendaraan di Jakarta akan terjebak kemacetan sesaat setelah keluar dari rumah pada tahun 2014 ("Jakarta Mengarah", 2009).

\section{Kecelakaan Lalu Lintas}

Kecelakaan lalu lintas dapat disebabkan oleh sejumlah faktor, misalnya kondisi kendaraan, lingkungan, dan pengendara, serta interaksi antar faktor-faktor tersebut. Namun demikian, karakteristik pengendara menyumbang proporsi terbesar. Hal ini sesuai dengan analisis Lewin (1982), bahwa faktor manusia berkontribusi terhadap kecelakaan lalu lintas sampai dengan 90\%. Tidak semua kecelakaan ini disebabkan oleh kekhilafan atau kekeliruan (error). Seringkali pengendara secara sengaja menyimpang dari perilaku berkendara yang aman (Reason, Manstead, Stradling, Baxter, \& Campbell, 1990). Penyimpangan ini mungkin disebabkan oleh sejumlah faktor, seperti misalnya kebutuhan sehari-hari (misalnya: berupaya untuk memenuhi janji di suatu tempat), karakteristik kepribadian (misalnya: kepribadian yang suka mencari sensasi), motivasi, dan bias-bias kognitif. Penyimpangan dari perilaku berkendara yang aman ini meningkatkan risiko sampai ke titik yang tidak terduga, bergantung pada komponen atau sifat dari peristiwa kecelakaan 
itu sendiri.

Risiko dan perubahan perilaku yang dihasilkannya merupakan konsep inti dalam penelitian tentang keamanan (safety). Risiko adalah setiap situasi yang dapat berakhir dengan hasil negatif, dan melibatkan dua komponen, yakni (1) kemungkinan hasil negatif, dan (2) tingkat beratnya hasil negatif (van der Pligt, 1996). Dalam mempelajari risiko, konstruk ini biasanya dipelajari sebagai sebuah konstruk subjektif dan multi-aspek. Penelitian-penelitian psikometris pada akhir 1970-an (Fischoff, Slovic, Lichtenstein, Read, \& Combs, 1978; sebagaimana dikutip dalam Kobbeltvedt, Brun, \& Laberg, 2004) membuktikan adanya sembilan aspek dari persepsi risiko, yakni (1) ketidaksengajaan paparan (involuntariness of exposure), (2) kesegeraan akibat (immediacy of effects), (3) ketiadaan pengetahuan yang akurat mengenai tingkat risiko (lack of precise knowledge about risk levels), (4) ketiadaan pengetahuan ilmiah (lack of scientific knowledge), (5) ketidakmampuan mengendalikan (uncontrollability), (6) kebaruan (newness), (7) potensi katastrofik (catastrophic potential), (8) perasaan cemas atau takut (feeling of dread), dan (9) konsekuensi mematikan (fatal consequences). Kesembilan aspek ini dapat dirunut kepada dua faktor, yakni (1) risiko yang ditakuti (dread risk), dan (2) risiko yang tidak diketahui (unknown risk). Risiko yang ditakuti dicirikan oleh persepsi tentang aspek no. (5), (7), (8), dan (9). Risiko yang tidak diketahui dicirikan oleh bahaya yang tidak teramati, bahaya yang tidak diketahui, serta bahaya baru. Faktor risiko yang ditakuti ditemukan berkorelasi tinggi dengan persepsi risiko apabila dibandingkan dengan faktor risiko yang tidak diketahui.

Pada masa yang lalu, pendekatan yang dilakukan untuk mengurangi kecelakaan utamanya difokuskan pada ukuran-ukuran rancang-bangun. Dengan perkataan lain, dengan memperbaiki atau meningkatkan infrastruktur, merancang jalan-jalan yang lebih aman, serta mewajibkan penggunaan sabuk pengaman dan helm SNI, diharapkan mengurangi tingkat fatalitas kecelakaan sampai derajat tertentu. Lebih jauh lagi, tindakan-tindakan regulatif juga dilakukan dengan menjadikan penggunaan sabuk pengaman sebagai kewajiban, pembatasan jumlah alkohol yang diperbolehkan ketika berkendara, serta pembatasan kecepatan laju kendaraan. Namun demikian, baik intervensi rancang-bangun maupun pengaturan-pengaturan hukum dapat berinteraksi dengan efek pilihanpilihan pribadi pengendara serta pilihan-pilihan yang tidak diniatkannya dalam mempengaruhi perilaku berkendaranya (Rothengatter, 2002).

Dengan perkataan lain, faktor manusia tidak dapat dikontrol tanpa upaya untuk memahami faktor-faktor psikologis yang mempengaruhi perilaku pengendara dan persepsi pengendara. Pengendara mengadaptasikan perilaku mereka menurut kebutuhan situasi dengan mempertimbangkan persepsi risiko dan persepsi tuntutan tugas mereka (Rothengatter \& Huguenin, 2004). Menurut Schlag (1999), pencegahan kecelakaan serta peningkatan keamanan berlalu lintas ini termasuk dalam area psikologi transportasi dan lalu lintas.

Terdapat tiga teori yang mengupas perilaku kompensatori pengendara: (1) Risk homeostasis theory (teori homeostasis risiko) dari Wilde (1982), (2) Zero risk theory (teori nol risiko) dari Summala (1974)_yang selanjutnya berkembang menjadi model hierarkis tentang adaptasi perilaku (1997), dan (3) Task capability model (model kapabilitas tugas) dari Fuller (2000).

Kompensasi risiko (risk compensation) merupakan perilaku adaptif dalam merespons 
perubahan-perubahan dalam risiko yang dipersepsikan seseorang. Apabila orang meyakini bahwa risikonya meningkat, maka ia akan mengambil tindakan pengamanan untuk mengurangi efek negatif dari situasi yang melibatkan risiko. Sebaliknya, jika orang mempersepsikan risiko itu rendah dan merasa aman, ia akan berperilaku kurang waspada serta siap menghadapi atau berkonfrontasi dengan situasi bahaya. Persoalan pokok dalam kompensasi risiko adalah persepsi tentang perubahan dalam tingkat risiko, yang akan menghasilkan perubahan perilaku (Hedlund, 2000). Bilamana pengendara merasa memiliki kebutuhan untuk mengadaptasikan perilaku mereka?

\section{Teori Homeostatis Risiko}

Gerald J. S. Wilde dalam Teori Homeostatis Risiko (1982) menghipotesiskan bahwa kita semua memiliki "tingkat risiko sasaran" (target risk level) serta mengukur risiko seperti sebuah termostat risiko. Perilaku berisiko melibatkan untung-rugi (costs and benefits). Tingkat risiko sasaran merupakan keuntungan bersih (net benefit) dari risiko yang diniatkan (intended risk). Dengan perkataan lain, tingkat risiko sasaran merupakan fungsi utilitas/kegunaan ekonomis dalam rangka memaksimalkan pencapaian bersih yang dikaitkan dengan dugaan kerugian dan keuntungan dari alternatif berisiko serta alternatif aman. Teori ini berasumsi bahwa orang membuat penilaian tentang risiko secara berkelanjutan. Apabila risiko yang dipersepsikan (perceived risk, subjective risk) tidak kongruen dengan tingkat risiko sasaran (target risk), maka orang akan mengadaptasikan perilaku mereka untuk memperkecil bahkan menghapus kesenjangan (sampai dengan nol) di antara keduanya. Jadi, apabila tingkat risiko yang dipersepsikan (subjective risk) lebih rendah daripada yang dapat diterimanya, maka orang cenderung untuk terlibat dalam tindakan yang meningkatkan keterpaparan mereka terhadap risiko.

Misalnya, apabila saat berkendara, hari mulai hujan, maka orang akan melambatkan kendaraannya untuk mengurangi kemungkinan celaka. Namun, apabila matahari bersinar kembali, mereka akan mempercepat laju kendaraannya sampai dengan titik di mana mereka merasa nyaman; hal ini menggambarkan tingkat risiko sasaran mereka. Contoh lainnya adalah pada tingkah laku pengendara melintasi rel kereta. Pada saat pengendara melihat dari jauh bahwa palang lintasan kereta belum benar-benar menutup (atau bahkan tidak ada palang), pengendara akan memiliki suatu peningkatan persepsi keamanan (penurunan persepsi risiko bahaya) untuk melintasi rel kereta. Persepsi tersebut akan berimplikasi pada peningkatan kecepatan, yang hasilnya adalah suatu persepsi subjektif keuntungan (dapat berhasil melintasi rel) yang sesungguhnya justru secara objektif tidak aman.

Teori Wilde mencakup sebuah lingkaran umpan balik (feedback loop) antara perilaku dan pencapaian (outcome), sebagaimana nampak dalam Gambar 1. Dengan demikian, perilaku pengendara yang penuh kehati-hatian tercermin dalam tingkat kerugian (injury rate), sementara tingkat kerugian juga tercermin dalam perilaku pengendara. Risiko sasaran merupakan konsep kunci dalam kausalitas sirkular ini. Teori ini menyatakan bahwa untuk mengurangi tingkat kerugian (meningkatkan perilaku aman), maka tingkat risiko sasaran yang ingin diambil oleh seseorang harus dikurangi (Wilde, 1998). 


\section{Teori Nol-Risiko}

Teori nol-risiko berfokus pada determinan motivasional, khususnya penilaian risiko subjektif pengendara dan perilaku kompensatori yang ingin diambil oleh mereka (Naatanen \& Summala, 1974). Summala memperluas pendekatan teoretis nol-risiko pengendara dari sejumlah aspek.

Model hierarkis adaptasi perilaku tugas pengendara dari Summala mempertimbangkan perubahan dalam sistem lalu lintas (changes in the traffic system) dalam menilai reaksi pengendara. Model ini dibangun dari kubus tugas tiga-dimensi (Summala, 1997). Model ini memandang tugas berkendara (driving task) sebagai interaksi antara (a) hierarki fungsional, (b) tingkat pemrosesan, dan (c) taksonomi fungsional. Dimensi hierarki fungsional memiliki kisaran dari kontrol kendaraan sampai dengan keputusan pergi (trip decisions) dan pilihan kendaraan. Dimensi taksonomi fungsional perilaku mencakup keterampilan berkendara, seperti melewati liukan jalan (lane keeping), menyeberang (crossing management), dan bermanuver (maneuvering). Tingkat pemrosesan psikologis ini membedakan antara kontrol perseptual-motor dan pengambilan keputusan serta tingkat pemantauan (supervisory monitoring level). Model ini menyatakan bahwa "semakin tinggi tugas dalam taksonomi fungsional, semakin sering pengambilan keputusan sadar dan pemantauan diterapkan". Kontrol perhatian (attention control) berada di antara kedua proses tersebut dan diterapkan baik top-down maupun bottom-up. Kontrol kecepatan dan kontrol waktu terletak di tengah kubus karena kedua faktor ini menentukan mobilitas dan merupakan tujuan motivasional utama berkendara.

\section{Model Kapabilitas Tugas}

Model kapabilitas tugas dari Fuller (2000) membedakan antara kompetensi pengendara dan kapabilitas pengendara. Kompetensi merupakan pencapaian keterampilan pengendara, yang mencakup keterampilan kontrol, keterampilan persepsi bahaya, dan keterampilan antisipasi serta defensif. Kapabilitas merupakan kemampuan pengendara untuk mentransfer tingkat kompetensinya dalam situasi tertentu.

Sejumlah besar hasil penelitian yang dipublikasi dalam jurnal-jurnal, seperti Accident Analysis and Prevention, Ergonomics, Safety Science, Human Factors, dan Transportation Research, menggambarkan keterbatasan umum manusia dalam hal: persepsi pengendara, pengambilan keputusan pengendara, dan eksekusi respons. Jurnal-jurnal tersebut menunjukkan bahwa terdapat banyak faktor individual dan faktor temporer yang dapat juga mempengaruhi seberapa efektif dan seberapa aman pengendara melakukan tugas mereka. Faktor-faktor tersebut mulai dari pendidikan dan pengalaman, alkohol dan agresi, sampai dengan kantuk dan stres. Faktor-faktor itu juga berkontribusi terhadap instabilitas kinerja pengendara, dan dapat berinteraksi dengan motivasi sesaat dari pengendara.

Mengendarai kendaraan dapat digambarkan sebagai tugas kendali dinamis (dynamic control task) dalam hal mana pengendara harus menyeleksi informasi yang relevan dari sejumlah besar 
masukan visual, untuk membuat keputusan dan menjalankan respons kendali yang tepat guna mencapai mobilitas yang aman. Meskipun terdapat situasi-situasi di mana pengendara harus bereaksi terhadap sejumlah peristiwa tak terduga (misalnya, seorang anak yang tiba-tiba keluar dari belakang sebuah kendaraan yang sedang diparkir), namun utamanya pengendara menjalankan tindakan yang direncanakan yang dibentuk oleh harapan-harapan mereka tentang bentangan jalan, pejalan kaki, dan skenario lalu lintas di depan mereka, serta realitas yang mereka amati secara aktual.

Dari Gambar 2 di atas, kita dapat melihat faktor-faktor kuncinya adalah lingkungan, yang disusun oleh jalan dan kondisi fisik seperti adhesi permukaan dan visibilitas jalan, pengguna jalan yang lain dengan siapa pengendara mungkin berinteraksi, serta tampilan/display informasi, kontrol, dan karakteristik operasional dari kendaraan yang dikendalikan oleh pengendara. Pengendara sendiri memiliki dua unsur tugas yang penting, yakni posisi di jalan dan kecepatan.

Pada saat melaksanakan tugasnya, pengendara membawa dalam dirinya karakteristik konstitusional tertentu, kapabilitas biologis yang menjadi unsur kinerja individual. Misalnya, ambang stimulus (jumlah energi minimum dalam sebuah stimulus yang dibutuhkan untuk dapat dideteksi kehadirannya oleh pengendara), kecepatan pemrosesan informasi, waktu reaksi, dan ketajaman penglihatan. Banyak dari unsur-unsur ini bervariasi secara sistematis sebagai fungsi dari usia. Berdasarkan karakteristik konstitusional ini, pengendara juga membawa dalam dirinya pengetahuan dan keterampilan yang berasal dari pendidikan dan pelatihan, yang dikembangkan dan diasah dengan pengalaman kumulatif. Secara bersama-sama, pendidikan dan pelatihan serta pengalaman kumulatif ini menentukan batas atas dari kapabilitas pengendara, yang disebut sebagai kompetensi pengendara.

Namun demikian, pengendara tidak selalu mampu untuk beroperasi pada tingkat kompetensi ini. Yang dapat dilaksanakan oleh pengendara pada momen waktu tertentu dapat dipengaruhi oleh sejumlah variabel yang disebut faktor-faktor manusia (human factors). Faktor-faktor ini mencakup kelelahan, kantuk, emosi, stres, distraksi, efek alkohol dan obat-obatan, serta motif-motif (seperti agresi). Faktor-faktor manusia tersebut berinteraksi dengan kompetensi pengendara untuk menghasilkan kapabilitas (Fuller \& Santos, 2002).

Gambar 3 dan Gambar 4 berturut-turut menunjukkan tuntutan tugas pengendara dan kapabilitas pengendara. Apabila kita mengintegrasikan kedua gambar tersebut, maka dapat dihasilkan model jembatan antar keduanya, yang kita sebut task-capability interface model (model jembatan tugaskapabilitas), sebagaimana nampak dalam Gambar 5.

Berdasarkan model ini, apabila kapabilitas melampaui tuntutan tugas, maka pengendara mampu untuk melaksanakan tugasnya secara aman. Namun jika kapabilitas lebih rendah daripada tuntutan tugas, maka akan terjadi tabrakan atau kehilangan kendali. Perkecualian terhadap hal ini adalah ketika pengguna jalan yang lain membuat manuver defensif atau meloloskan diri, misalnya seorang pejalan kaki melompat keluar dari jalan yang sedang dilalui kendaraan si pengendara yang kehilangan kontrol ini. Manuver semacam itu mengubah secara efektif tuntutan tugas pada sebuah momen kritis.

Pertanyaan berikutnya adalah, setelah kita mengetahui unsur-unsur kunci yang berkontribusi 
terhadap model ini, lalu apakah yang memberikan energi kepada model ini? Apakah yang membuat model ini bergerak? Guna menjawab pertanyaan ini, Fuller menyampaikan sebuah hipotesis kerja sebagai berikut. Bahwa untuk hampir seluruh waktunya, pengendara berkendara sedemikian rupa untuk mencapai mobilitasnya, untuk mencapai tujuan perjalanannya, dan sementara itu memastikan bahwa kesulitan tugas tetap berada dalam batas-batas yang dapat diterima. Jadi, apabila hal-hal menjadi sangat hectic (sibuk dan cepat) di jalan, terlalu menuntut, maka pengendara akan melambatkan laju kendaraannya. Apabila tugas terlampau mudah, maka pengendara meningkatkan laju kendaraannya, sehingga menjadi lebih menantang. Hal ini disebut sebagai homeostasis tugaskesulitan (task-difficulty homeostasis).

Dalam proses ini, (1) kapabilitas pengendara, sebagaimana yang dipersepsikan oleh pengendara itu sendiri, serta (2) motivasi pengendara untuk melibatkan diri dalam tingkat kesulitan tugas tertentu, secara bersama-sama menentukan rentang kesulitan tugas yang menjadi sasaran pengendara. Interaksi dinamis antara pengendara dengan bentangan jalan dan skenario lalu lintas menentukan kesulitan tugas objektif. Kedua hal ini (kesulitan tugas objektif dan sasaran kesulitan pengendara) kemudian diperbandingkan. Jika kesulitan melampaui (atau: diantisipasi untuk melebihi) sasaran kesulitan pengendara, maka pengendara mengambil tindakan untuk mengurangi tingkat kesulitan (misalnya dengan memperlambat laju kendaraan). Di sisi lain, jika kesulitan yang dipersepsikan lebih rendah daripada sasaran, maka pengendara mengambil tindakan untuk meningkatkan tingkat kesulitan (misalnya dengan mempercepat laju kendaraan).

Ringkasnya, model Fuller menyatakan bahwa kesulitan tugas (task difficulty) berasal dari kesenjangan antara upaya pengendara untuk merespons tuntutan tugas dan tingkat kapabilitas yang tersedia (Gambar 6). Apabila tuntutan tugas melebihi kapabilitas pengendara, maka tugas dipersepsikan sebagai sulit dan berisiko. Hasil dari ketidaksesuaian ini dapat menjadi sebuah kecelakaan. Guna mengelola kesulitan tugas, pengendara dapat memodifikasi tuntutan tugas atau kapabilitasnya.

\section{Kelemahan Teori Risiko}

Ketiga teori risiko yang dikemukakan di atas mencoba untuk menjelaskan perilaku pengendara dan bagaimana mereka menangani risiko dalam berlalu lintas. Teori-teori tersebut tidak mempertimbangkan apakah prakiraan risiko pengendara akurat ataukah tidak. Kenyataan bahwa pengendara tetap mengalami kecelakaan meskipun terdapat peningkatan dalam hukum, regulasi, dan rancang-bangun mengindikasikan bahwa pengendara gagal untuk mengestimasi risiko secara akurat. Terdapat kesenjangan antara risiko yang dipersepsikan dan risiko objektif. Estimasi atau prakiraan risiko mengalami bias oleh proses-proses kognitif, konteks, serta karakteristik personal dan kultural. Meskipun pengendara nampaknya sadar terhadap risiko yang terkait dengan tingkah laku tertentu, mereka gagal untuk memperkirakan secara akurat kekuatan (magnitude) risiko bagi diri mereka sendiri.

Teori atribusi dapat membantu untuk memahami mengapa pengendara memiliki kecenderungan untuk memiliki bias estimasi. Riset atribusi menyatakan bahwa proses atribusi (sebagai istilah 
payung untuk upaya individu untuk mencari hubungan kausal dari peristiwa-peristiwa yang terjadi di sekitarnya) diwarnai oleh sejumlah kekeliruan dan bias sistematis. Kekeliruan dan bias ini mungkin disebabkan oleh keterbatasan sistem kognitif, faktor-faktor motivasional, atau keduanya. Salah satu bias ini adalah bias melayani diri sendiri (self-serving bias), yang merupakan kecenderungan untuk menginterpretasikan dan menjelaskan hasil dengan cara-cara yang menguntungkan (favorable) bagi diri sendiri. Self-serving bias memiliki dua faset: (a) bias peningkatan diri (self-enhancement bias), dan (b) bias perlindungan diri (self-protective bias). Bias peningkatan diri bertanggung jawab bagi hasil-hasil yang sukses, sedangkan bias perlindungan diri menolak untuk bertanggung jawab bagi hasil-hasil negatif (Blaine \& Crocker, 1993).

Dengan mengaplikasikan konsep self-serving biases pada penilaian risiko menyatakan bahwa orang memiliki kecenderungan untuk membuat atribusi terhadap disposisi apabila mereka memperoleh hasil positif sebagai hasil dari peristiwa yang melibatkan risiko (risk-involving). Sebaliknya, orang tidak suka membuat atribusi disposisional bagi hasil-hasil negatif dari peristiwa berisiko. Kegagalan dalam mengasosiasikan perilaku dan risiko akan menimbulkan persistensi (kegigihan) dalam mempertahankan perilaku berisiko khususnya apabila hasilnya tidak negatif. Taylor dan Brown (1988) menyatakan bahwa sifat alami self-serving dalam hal prakiraan risiko mungkin disebabkan oleh keyakinan kontrol yang dilebih-lebihkan dan bias optimisme. Dengan perkataan lain, kontrol dan optimisme yang bersifat overestimasi atau superior menimbulkan reduksi dalam persepsi risiko dan meningkatkan kecenderungan perilaku pengambilan risiko. Oleh karena itu, pengaruh ilusi kendali, bias optimisme, dan lokus kendali terhadap perilaku pengambilan risiko perlu dipertimbangkan.

\section{Rekomendasi Intervensi untuk Masalah Kemacetan Lalu Lintas}

\section{Tingkat Individual}

Orang perlu ditingkatkan kesadarannya tentang dilema sosial. Orang tidak selalu menyadari bahwa perilaku mereka berkonsekuensi negatif terhadap banyak orang lain, dalam hal ini kemacetan lalu lintas dan polusi lingkungan yang diakibatkan oleh masifnya penggunaan kendaraan pribadi. Penelitian menunjukkan bahwa semata-mata pemberian informasi tentang dilema sosial dapat mempengaruhi secara kuat keputusan orang (Komorita \& Parks, 1994). Karenanya, perlu disampaikan pesan bahwa jalan akan lancar, waktu tempuh akan menjadi lebih pendek, apabila sejumlah orang berkontribusi dengan perilakunya masing-masing. Artinya, kontribusi satu-dua orang saja tidak akan memiliki pengaruh yang signifikan untuk mengatasi kemacetan lalu lintas. Namun demikian, perasaan tiadanya efikasi personal (keyakinan akan keberhasilan kontribusi pribadi) ini merupakan salah satu rintangan utama bagi individu untuk bekerjasama, terutama dalam dilema sosial dengan jumlah orang yang besar (Kerr, 1996). Apabila sejumlah pengendara 
kendaraan pribadi dapat dipersuasi untuk menggunakan transportasi publik (ketimbang mobil pribadi, misalnya), maka pengendara yang lain ("free-riders") akan menikmati keuntungan karena lalu lintas yang kurang macet. Hal ini akan menginspirasi orang untuk menggunakan kendaraan pribadinya kembali. Ditambah lagi, penggunaan mobil memberikan sejumlah keuntungan langsung, khususnya terciptanya perasaan akan kebebasan dan kemandirian serta kenyamanan. Oleh karena itu, perlu diadakan kampanye informasi publik yang berkelanjutan yang tidak hanya menekankan pentingnya warga berkontribusi dengan perilakunya, tetapi juga menekankan bahwa kontribusi dari masing-masing individu memang sungguh-sungguh dapat "membuat perbedaan hasil".

Individu dapat diedukasi untuk mengubah orientasi nilai, dari pro-diri menjadi pro-sosial (van Vugt dalam Messick \& McClintock, 1968). Pro-diri berarti orang memaksimalkan pencapaian/keuntungannya sendiri, sedangkan pro-sosial berarti orang memaksimalkan pencapaian kolektif/bersama. Orientasi prososial ini hendaknya dikombinasikan dengan faktor krusial lain dalam sosial dilema, sebagaimana dinyatakan oleh Dawes (1980), yakni bahwa orang harus memiliki sejumlah alasan untuk percaya bahwa orang lain tidak akan bertingkah laku defektif. Tingkah laku defektif maksudnya adalah tingkah laku yang melestarikan terjadinya Tragedi Bersama. Bahwa meskipun perbedaan dalam hasil (payoffs) memang selalu menguntungkan pelaku defektif tidak peduli apa yang dilakukan orang lain, namun orang perlu percaya bahwa hasil absolut (absolute payoff) - tiadanya kemacetan - selalu lebih tinggi apabila semua orang bekerjasama untuk mengatasi kemacetan lalu lintas ini, misalnya dengan bersama-sama menggunakan transportasi publik. Kepercayaan ini harus terus dibangun terus-menerus. Memang tidak mudah, tetapi mungkin.

\section{Tingkat Kultural}

Kita perlu memperkuat norma dalam situasi dilema sosial. Dalam situasi dilema sosial yang terjadi di dunia nyata, seperti dalam berlalu lintas ini, keputusan sebagian besar dibuat secara anonim. Dengan demikian orang dapat secara mudah menyangkal tanggung jawabnya dalam menciptakan atau memecahkan permasalahan. Solusi terhadap hal ini adalah dengan membuat menonjol norma sosial yang menekankan kerja sama. Contoh: (1) Penghargaan untuk "kota nol kemacetan atau nol kecelakaan"; hal ini menciptakan perbandingan sosial (social comparison) dan perlombaan yang sehat antar kota; (2) Program anti-kemacetan dan anti-kecelakaan diselenggarakan pada tingkat komunitas, sehingga orang lebih berkomitmen untuk memecahkan masalah yang terjadi pada lingkungan di depan matanya (direct environment); (3) Program pengawasan masyarakat, dalam hal mana para pelanggar, misalnya pengendara motor yang berupaya menyeberang, menaikkan motornya pada jembatan penyeberangan (yang seharusnya hanya untuk pejalan kaki) dilaporkan secara langsung ke polisi terdekat agar dapat diidentifikasi dan dihukum.

Agar kemacetan dapat dikurangi karena adanya pungutan liar (pungli) di jalan-jalan yang memperlancar kendaraan tertentu saja, maka di samping perlu diusahakan adanya polisi yang tegas di jalan-jalan yang rawan pungli; maka perlu dibangun suatu budaya masyarakat yang menolak 
pungli. Masyarakat perlu kompak untuk menolak pungutan liar, tidak memanfaatkan "kesempatan dalam kesempitan". Dengan demikian, transaksi pungli menjadi "mau untung jadi buntung" (pembalikan manfaat).

\section{Tingkat Struktural}

Strategi lain yang dapat digunakan untuk mengatasi kemacetan lalu lintas adalah dengan menerapkan reward untuk tingkah laku yang mendukung teratasinya tragedi bersama dan punishment untuk tingkah laku yang tidak mendukung. Penggunaan transportasi publik dapat dipromosikan dengan memberikan reward berupa keringanan pajak (tax benefits) bagi orang-orang yang memiliki dan rutin menggunakan kartu busway atau kereta. Di samping itu, punishment dapat dilakukan dengan menaikkan pajak mobil mewah atau pajak bahan bakar mobil. Keberhasilan dari intervensi ini sangat bergantung pada besarnya reinforcement (reward dan punishment) serta konsistensi pemberiannya (van Lange \& Messick, 1996).

Hal yang penting juga adalah bahwa bentuk insentif harus bermakna bagi orang. Misalnya, dalam hal moda transportasi, penelitian van Vugt, Meertens, \& van Lange. (1995) menunjukkan bahwa para pelaku bisnis akan berubah dari menggunakan mobil menjadi menggunakan transportasi publik apabila hal ini lebih efisien dan memberikan status yang baik. Misalnya, busway yang digunakan cepat, aman, dan terdapat kesan mewah (dengan adanya televisi, koneksi internet, dll). Hal ini dapat dipahami karena suasana yang demikian merupakan suasana yang kongruen dengan konsep diri para pelaku bisnis pada umumnya.

Solusi struktural terakhir adalah dengan mengeliminasi (baik sebagian atau pun seluruhnya) interdependensi antar orang dalam situasi dilema sosial. Dalam literatur dilema sosial, strategi ini disebut privatisasi (Messick \& Brewer, 1983). Jadi, orang yang lebih mampu, jika menggunakan BBM, tidak diberlakukan tarif normal/rata-rata (flat rate tariff), melainkan dikenakan biaya sesuai dengan penggunaannya. Penggunaan yang semakin banyak berarti harga yang dibayar harus semakin mahal.

\section{Rekomendasi Intervensi untuk Masalah Kecelakaan Lalu Lintas}

\section{Tingkat Individual}

Berdasarkan teori mutakhir dari Fuller (2000), serta Fuller dan Santos (2002), nampak bahwa keamanan berkendara terancam apabila terdapat kesenjangan antara kesulitan tugas yang dipersepsikan pengendara (perceived task difficulty) dengan kesulitan tugas objektif (objective task difficulty), khususnya ketika pengendara menganggap remeh kesulitan tugas objektif. Solusi untuk mengatasi hal ini adalah dengan memberikan pengendara informasi yang jelas, ilmiah, dan andal, yang mencakup informasi mengenai kecepatan, jurusan kendaraan, tingkat adhesi jalan, serta halhal lain apa pun yang berpotensi menjadi bahaya. 


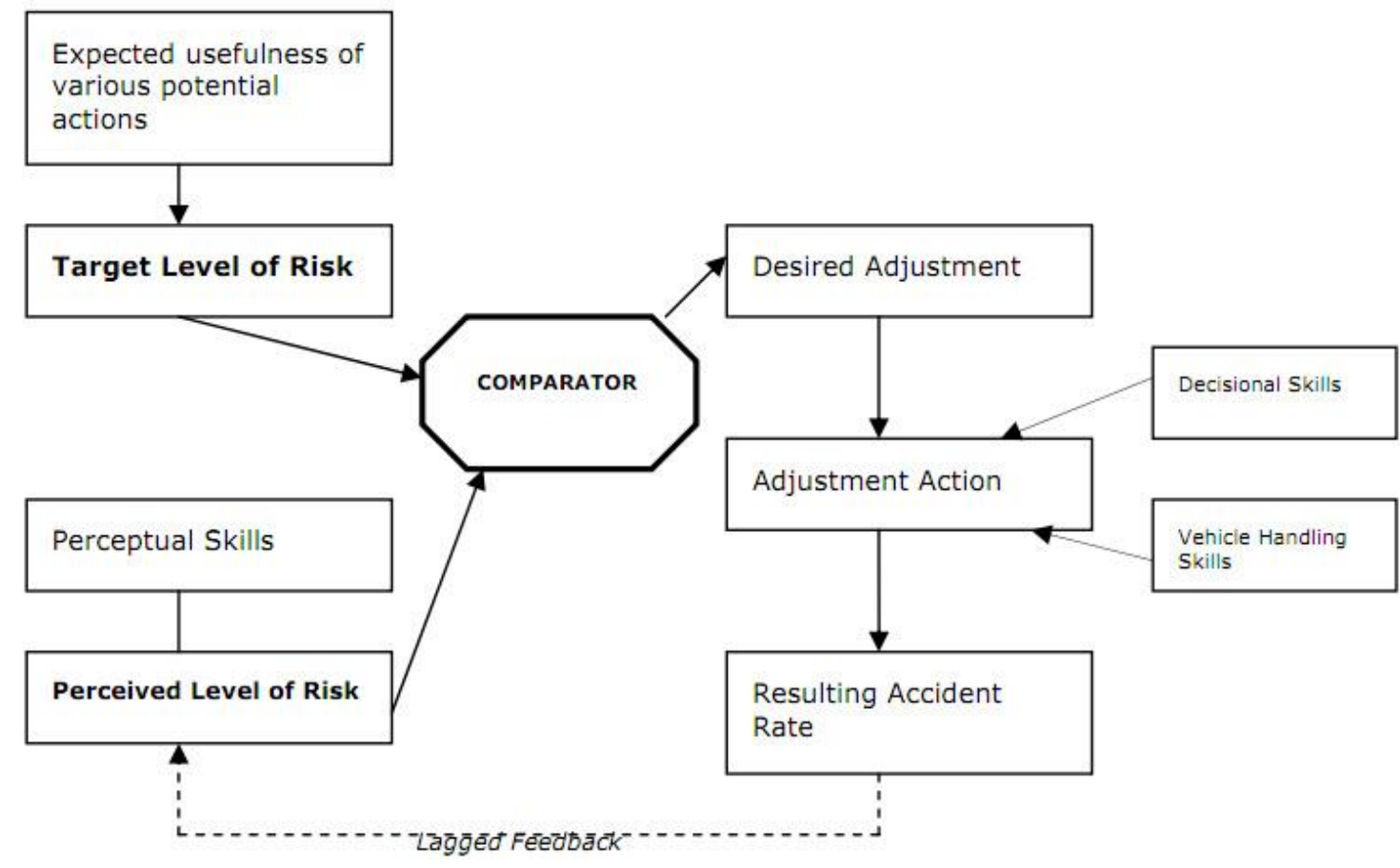

Gambar 1. Model homeostatis dari Wilde (1982, h. 212)

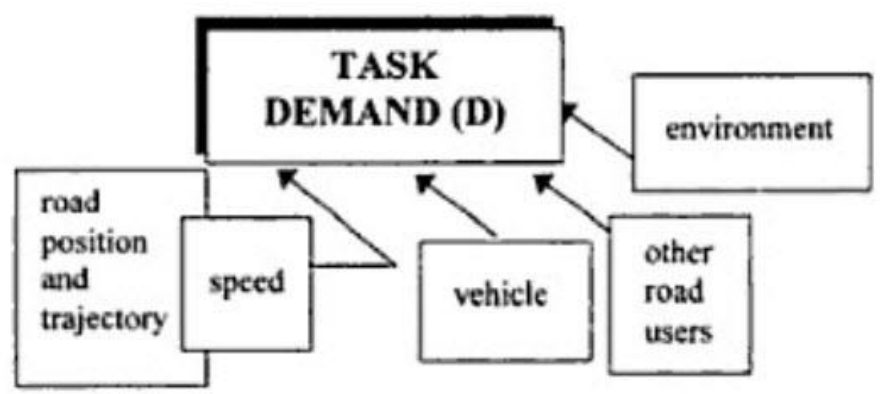

Gambar 2. Faktor-faktor yang berkontribusi terhadap tuntutan tugas bagi pengendara (Fuller \& Santos, 2002, h. 4) 


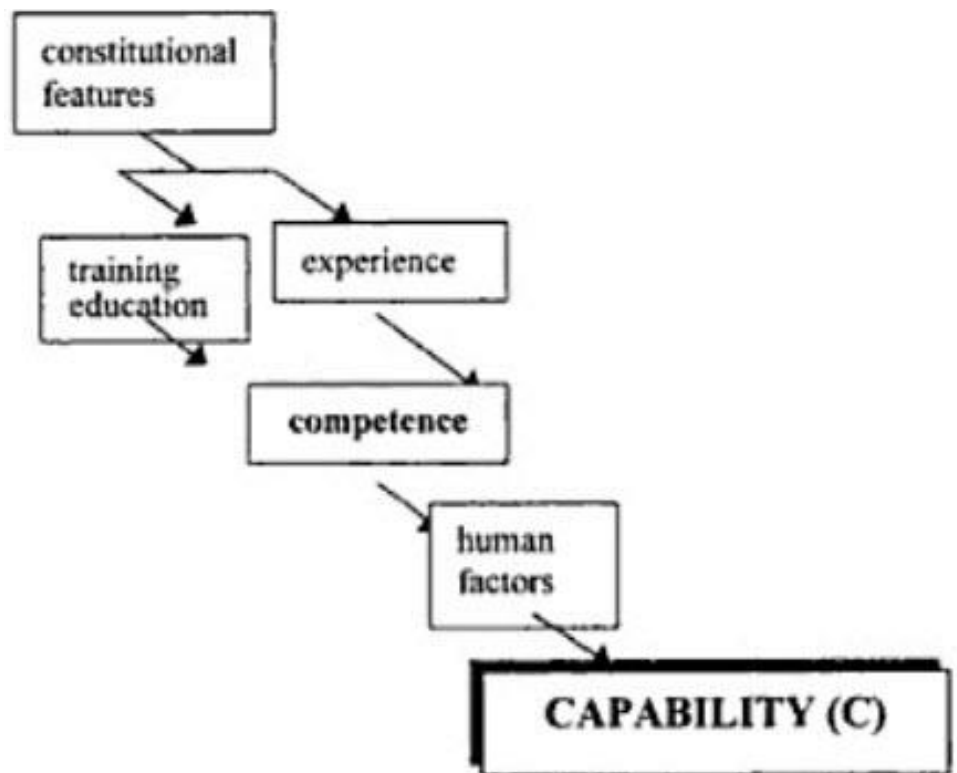

Gambar 3. Determinan kapabilitas pengendara (Fuller \& Santos, 2002, h. 5)

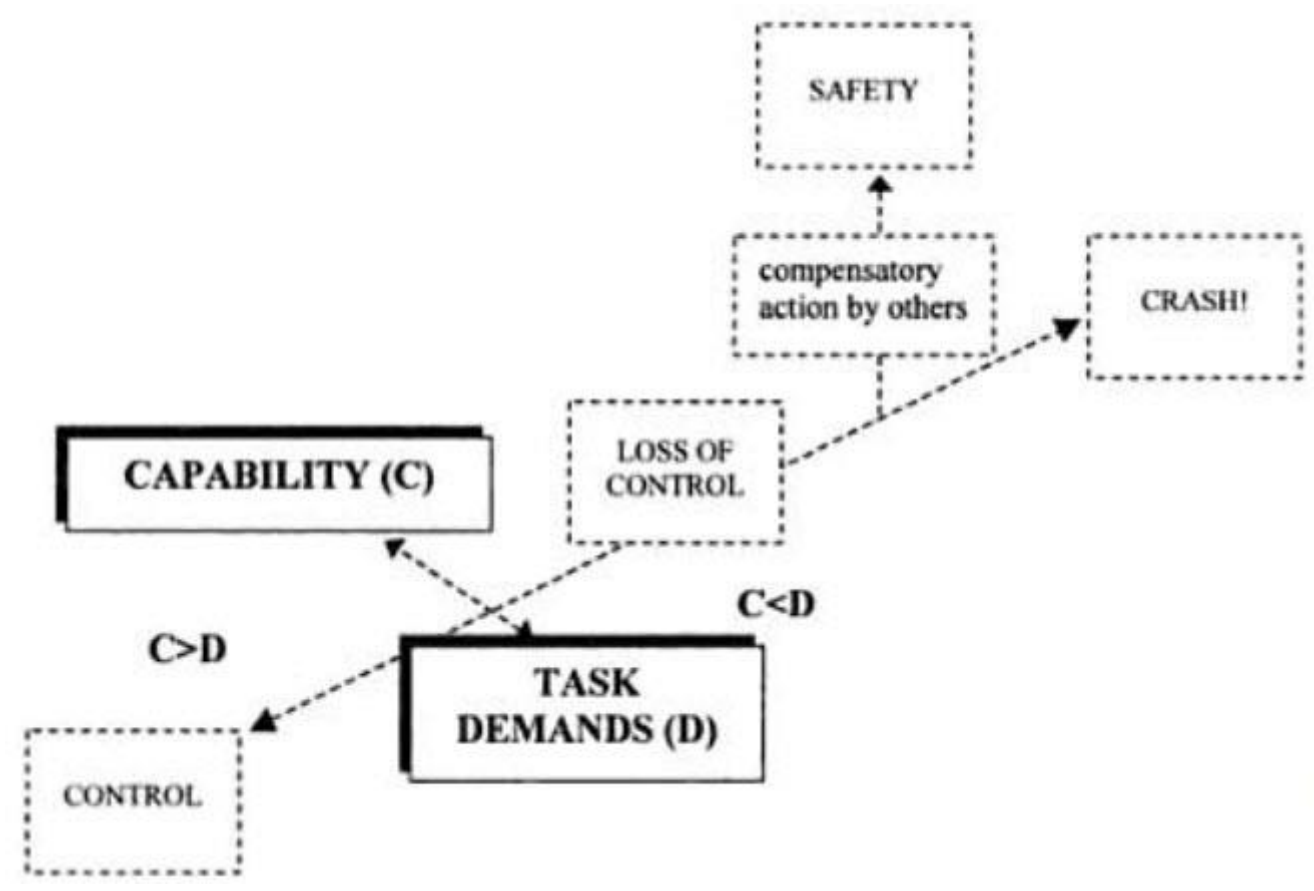

Gambar 4. Kemungkinan hasil dari jembatan antara tuntutan tugas dan kapabilitas pengendara (Fuller \& Santos, 2002, h. 6) 


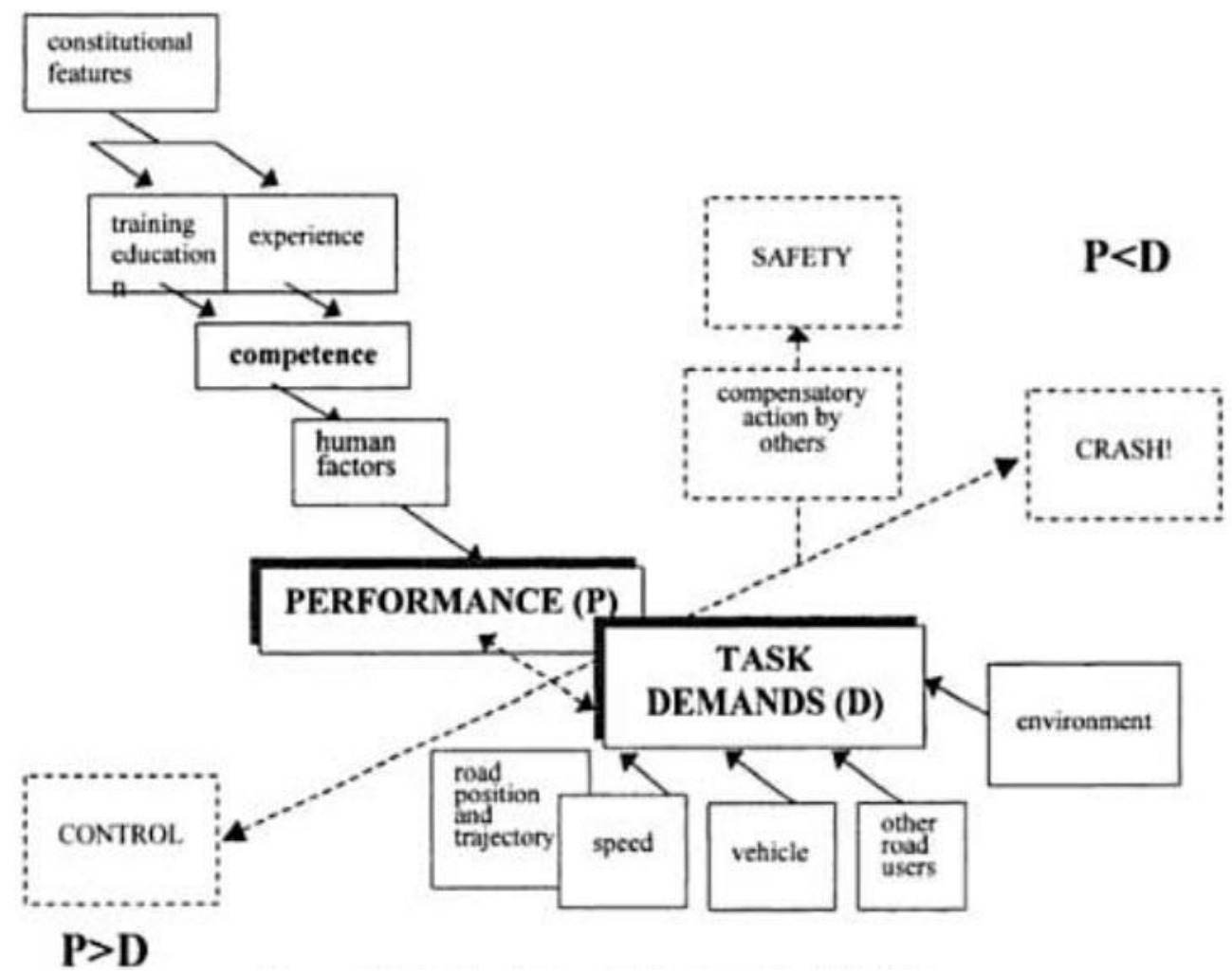

Gambar 5. Model Jembatan Tugas-Kapabilitas (Fuller \& Santos, 2002, h. 7)

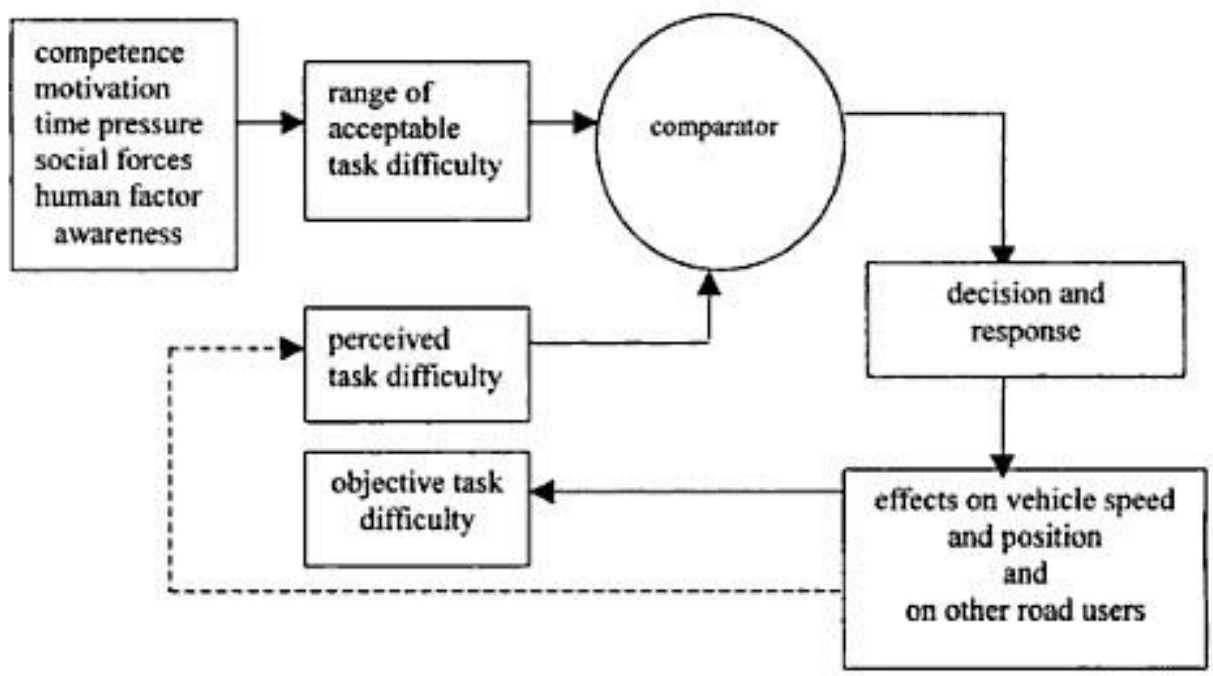

Gambar 6. Homeostatis kesulitan tugas (Fuller \& Santos, 2002, h. 8) 


\section{Tingkat Kultural}

Dari sisi kultural, Wilde (1985) telah memberikan empat pendekatan untuk mengurangi tingkat risiko sasaran pengendara (baca: mengurangi kejadian kecelakaan), yakni (1) meningkatkan penghargaan kepada perilaku aman (misalnya, dengan memberikan insentif), (2) menghukum perilaku yang berisiko atau tidak aman, (3) menurunkan keuntungan dari perilaku berisiko (misalnya, jangan memberikan sebutan "hebat" / heroism kepada perilaku tersebut), dan (4) menurunkan konsekuensi negatif dari perilaku aman (misalnya, jangan membiarkan terjadinya kehilangan waktu / time loss pada para pengendara yang berperilaku aman).

Selanjutnya, Wilde dan Robertson (2002) menambahkan dua pendekatan lagi, yakni (1) memberikan penghargaan kepada pengendara yang tidak mengalami kecelakaan (misalnya, mengenakan premi asuransi yang lebih murah kepada pengendara yang tidak pernah melakukan klaim asuransi; hal ini disebut "no-claim bonus"), dan (2) menghukum pengendara yang mengalami kecelakaan. Namun demikian, teori ini tidak memperhitungkan regulasi/peraturan keamanan lingkungan, seperti rancangan jalan dan kendaraan (Hedlund, 2000; Rothengatter, 2002). Hal ini dapat dipahami karena asumsi teori ini adalah bahwa modifikasi lingkungan atau pengaturan perilaku pengendara tanpa mempengaruhi tingkat risiko sasaran adalah kesia-siaan belaka.

\section{Tingkat Struktural}

Menurut Fuller dan Santos (2002), ketika tuntutan tugas (demands of the task) melampaui kapabilitasnya, dan pada saat yang sama pengendara tidak dapat melakukan apa-apa untuk mereduksi tuntutan tugas atau pun untuk meningkatkan kapabilitasnya, maka pengendara akan memilih untuk menghindari kondisi tersebut (kondisi tuntutan tugas yang berlebih). Hal ini menjelaskan paradoks mengapa intervensi keamanan yang bersifat membuat tugas menjadi mudah (misalnya meluruskan jalan yang tadinya berbentuk kurva) justru menyebabkan perilaku berisiko seperti peningkatan kecepatan oleh pengendara.

Berdasarkan pengetahuan tersebut, maka intervensi keamanan yang bersifat membuat tugas nampak menjadi lebih sulit (misalnya, liukan/putaran "S", leher jalan, pintu gerbang, penyempitan jalan) patut dipertimbangkan. Jadi diperlukan rancangan yang membuat tugas nampaknya lebih sulit daripada kesulitan objektifnya, sehingga pengendara dapat memperlambat laju kendaraannya. Hal ini dapat dikombinasikan dengan paparan peringatan data statistik kejadian kecelakaan lalulintas yang diletakkan di jalan. Pendekatan kombinatif ini diperlukan karena, sebagaimana dinyatakan oleh Baron, Byrne, dan Branscombe (2005), pesan-pesan yang berbingkai negatif (negatively framed) sebagai strategi preventif dan ditolak orang. Hal ini disebabkan karena pesanpesan yang mencemaskan, dan menimbulkan afeksi ketakutan seperti itu bersifat mengancam diri (self) seseorang, sehingga dapat mengaktifkan mekanisme pertahanan (defense mechanism) dalam rangka mempertahankan citra diri (self-image) yang positif; selanjutnya, hal ini mengganggu kemampuan orang untuk menaruh perhatian pada sebuah pesan untuk mengingat bahaya dari 
JUNEMAN

perilakunya. 


\section{Bibliografi}

Angka kecelakaan lalu lintas meningkat. (2009, 25 Juni). Liputan 6. Diakses dari http://berita.liputan6.com/sosbud/200906/234785/Angka.Kecelakaan.Lalu.Lintas.Tahun.Ini.Me ningkat, pada 5 Januari 2010.

Baron, R.A., Byrne, D., \& Branscombe, N. (2005). Social psychology (Edisi ke-11). Boston: Allyn $\&$ Bacon.

Blaine, B \& Crocker J. (1993). Self-esteem and self-serving biases in reactions to positive and negative events: An integrative review. Dalam Baumeister, R. F. (Ed.). Self-esteem: The puzzle of low self-regard (h. 55-85). New York,USA: Plenum Press.

Dawes, R.M. (1980). Social dilemmas. Annual Review of Psychology, 31, 169-193.

Di Jakarta, setiap hari empat orang tewas akibat kecelakaan lalin (2009, 21 Desember). Republika. Diakses dari http://www.republika.co.id/berita/breaking-news/metropolitan/09/12/21/97040-dijakarta-setiap-hari-empat-orang-tewas-akibat-kecelakaan-lalin, pada 5 Januari 2010.

Fuller, R. (2000). The task-capability interface model of the driving process. Recherche, Transports, Sécurité, 66, 47-59.

Fuller, R., \& Santos, J. A. (2002). Human factors for highway engineers. Emerald Group Publishing.

Hardin, G. (1968, 13 Desember). The tragedy of the commons. Science, 162(3859), 1243-1248.

Hedlund, J. (2000). Risky business: Safety regulations, risk compensation, and individual behavior. Injury Prevention, 6, 82-90.

Jakarta mengarah pada kemacetan total. (2009, 19 Juni). Kompas.com. Diakses dari http://nasional.kompas.com/read/2009/06/19/06125151/jakarta.mengarah.pada.kemacetan.total, pada 5 Januari 2010.

Kerr, N. L. (1996). Does my contribution really matter: The role of efficacy in social dilemmas. European Review of Social Psychology, 7, 209-240.

Kobbeltvedt, T., Brun, W., \& Laberg, J.C. (2004). Measuring and modelling risk in a naturalistic setting. Journal of Risk Research, 7, 789-810.

Komorita, S. S. \& Parks, C. D. (1994). Social dilemmas. Dubuque, IA: Brown \& Benchmark.

Lewin, I. (1982). Driver training: A perceptual-motor skills approach. Ergonomics, 25, 917-924.

Messick, D. M. \& Brewer, M. B. (1983). Solving social dilemmas: A review. Review of Personality and Social Psychology, 4, 11-44. Beverly Hills, CA: Sage.

Messick, D. M., \& McClintock, C. G. (1968). Motivational bases of choice in experimental games. Journal of Experimental Social Psychology, 4, 1-25.

Naatanen, R. \& Summala, H. (1974). A model for the role of motivational factors in drivers' decision-making. Accident Analysis and Prevention, 6, 243-261.

Reason, J., Manstead, A, Stradling, S.G., Baxter, J., \& Campbell, K. (1990). Errors and violations on the roads: A real distinction? Ergonomics, 33(10/11), 1315-1332.

Rothengatter, J. A. (2002). Drivers' illusions- no more risk. Transportation Research Part F, 5, 249-258.

Rothengatter, T. \& Huguenin, R. D. (2004). Introduction. Dalam Rothengatter, T., \& Huguenin, R. 
D. (Eds.), Traffic and transport psychology (h. 3-7). Amsterdam, Netherlands: Elsevier.

Schlag, B. (Ed.). (1999). Empirische verkehrspsychologie [Empirical traffic psychology]. Lengerich, Berlin: Pabst Science Publishers.

Sepanjang 2009, angka kecelakaan "busway" 268 kasus (2009, 25 Desember). Kompas.com.

Diakses

dari

http://female.kompas.com/read/2009/12/25/13281751/Sepanjang.2009.Angka.Kecelakaan.Bus way.268.Kasus, pada 5 Januari 2010.

Shaw, M. E., \& Costanzo, P. R. (1970). Theories of social psychology. McGraw-Hill, New York.

Summala, H. (1997). Hierarchical model of behavioural adaptation and traffic accidents. Dalam Rothengatter, J. A., \& Carbonell Vaya, E. (Eds.), Traffic and transport psychology: Theory and application. Oxford: Pergamon.

Susanto, B. (2006). Tol di tengah kota: Solusi atau masalah baru? Dalam Verdiansyah, C., Politik kota dan hak warga kota. Jakarta: Penerbit Buku Kompas.

Taylor, S. E. \& Brown, J. D. (1988). Illusion and well-being: A social psychological perspective on mental health. Psychological Bulletin, 103(2), 193-210.

van der Pligt, J. (1996). Risk perception and self-protective behavior. European Psychologist, 1(1), 34-43.

van Lange, P. A. M. \& Messick, D. M. (1996). Psychological processes underlying cooperation in social dilemmas. Dalam Gasparski, W., Mucki, M. \& Banathy, B. (Eds), Social agency: dilemmas and educational praxiology (vol.4). New Brunswick: Transaction.

van Vugt, M., Meertens, R. M. \& van Lange, P. A. M. (1995). Car versus public transportation? The role of social value orientations in a real-life social dilemma. Journal of Applied Social Psychology, 25, 258-278.

Wilde, G. J. S. (1982). The theory of risk homeostasis: Implications for safety and health. Risk Analysis, 2, 209-225.

Wilde, G. J. S. (1985). The use of incentives for the promotion of accident free driving. Journal of Studies on Alcohol, 10, 161-167.

Wilde, G. J. S. (1998). Risk homeostasis theory: An overview. Injury Prevention, 4, 89-91.

Wilde, G. J. S., \& Robertson, L. (2002). For and Against: Does risk homoeostasis have implications for road safety. British Medical Journal, 324, 1149-1152. 
MASALAH TRAN 